\title{
Methodology for the in situ testing of the moisture content of brick walls: an example of application
}

\author{
Anna Hoła ${ }^{1}$ (D) \\ Received: 21 February 2020 / Revised: 5 September 2020 / Accepted: 15 September 2020 \\ (c) The Author(s) 2020
}

\begin{abstract}
The article presents original methodology of testing the moisture content of brick walls in buildings. It was developed on the basis of own experience acquired during testing the moisture content in many excessively wet buildings erected in various historical periods. The tests were conducted using different methods, including non-destructive methods. To emphasize the importance of the problem, an overview of the methodology was preceded by a brief presentation of the causes and negative effects of excessive moisture and salinity in brick walls. In addition, the article is illustrated with an example of the effects of moisture content tests carried out according to the developed methodology on a facility from the fourteenth century. According to the author, knowledge of the presented methodology, and its application, should contribute to both the improvement of the quality of conducted research and the credibility of the obtained results.
\end{abstract}

Keywords Brick walls $\cdot$ Moisture content $\cdot$ Research methodology $\cdot$ Non-destructive methods

\section{Introduction}

A lot of masonry buildings, the preservation of which in good technical condition is in the public interest due to their historical value, as well as some buildings erected relatively recently have excessively damp and saline walls. The universality of the issue is demonstrated by the fact that the subject of numerous publications are case studies of often very valuable historically buildings that are excessively moist and located in various places all around the world [e.g. [1-5]. This problem not only refers to the brick walls of underground, ground floor, and above ground walls, but also often to the vaults above basements. The walls in question may be made of homogeneous material or have a core made of brick debris and lime mortar, which in the latter case means that they are characterized by a very high active porosity [6].

Excessive moisture is a result of the direct and long-term contact of a wall with soil—due to the lack of horizontal and vertical damp-proof insulation, which was previously not made, or in the case of newer buildings was incorrectly

Anna Hoła

anna.hola@pwr.edu.pl

1 Faculty of Civil Engineering, Wroclaw University of Science and Technology, Wybrzeze Wyspianskiego 27, 50-370 Wrocław, Poland executed. The water contained in the ground, together with the salts dissolved in it, gradually penetrates a wall due to capillary rising, and then moves into its higher parts, causing the wall to be damp and saline. The consequences of this process include, among others, the progressive destruction of plaster, bricks and mortar, the deterioration of the thermal properties of the partition, and therefore the deterioration of the operating conditions in rooms, etc. (Fig. 1).

Excessive moisture and salinity are defined in this publication based on the classifications adopted in the technical literature [7-9], according to which the permissible level of the mass moisture content of a brick wall $U_{\mathrm{m}}$ is considered to be equal to $3 \%$. If the mass moisture content exceeds $5 \%$, it is absolutely necessary to take measures to reduce it to an acceptable level. In turn, the acceptable salinity is considered to be one where the concentration of which does not exceed low levels (Table 1).

The starting point for solving the problem of excessive moisture, and stopping the processes of a wall's destruction that was caused by it, is to perform reliable tests of the level of moisture content and salinity. Non-destructive methods are very often used in moisture content tests, especially in relation to objects of high historical value. These tests should form the basis for making accurate decisions regarding any further proceedings with a damp wall, primarily regarding the choice of the optimal method (for a given situation) of 


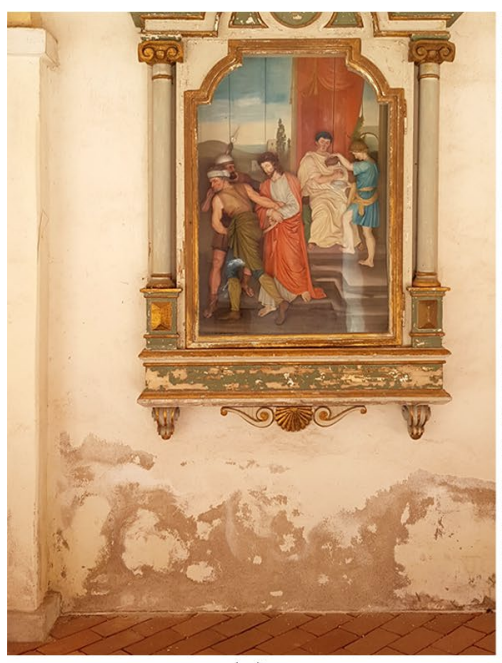

(a)

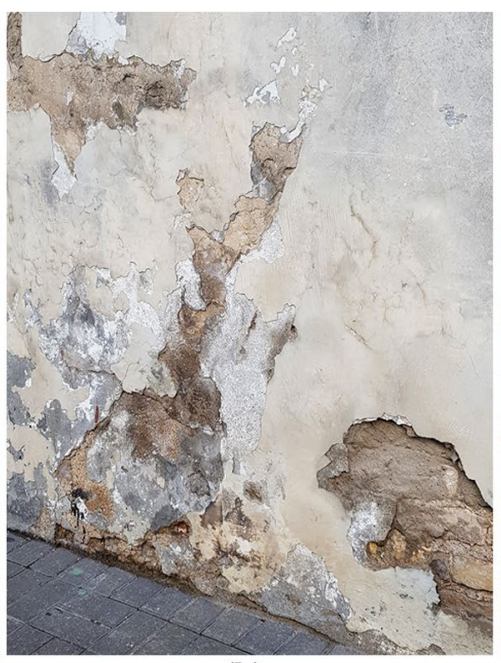

(b)

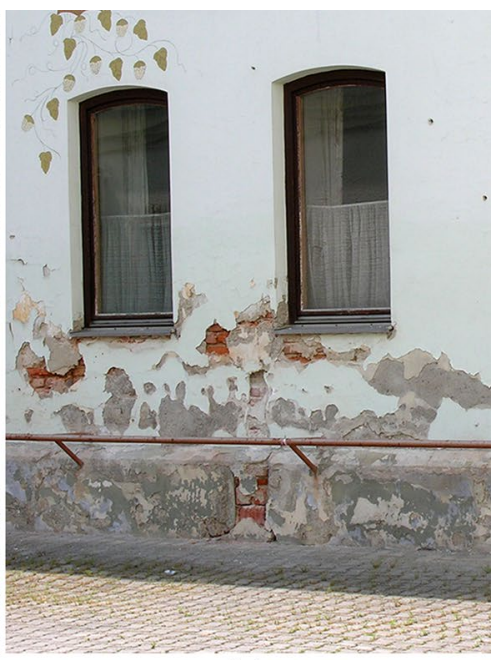

(c)

Fig. 1 Exemplary view of damage to plaster, bricks, and mortar caused by the excessive moisture and salinity of a brick wall: a in Poland; $\mathbf{b}$ in Latvia; $\mathbf{c}$ in Germany

Table 1 Classification of the moisture content and salinity of brick walls according to [7-10]

\begin{tabular}{lll} 
Moisture classification & & \\
Moisture content $U_{\mathrm{m}}$ in $\%$ & $<3.0$ & Wall with a permissible moisture content \\
& $3.0-5.0$ & Wall with an increased moisture content \\
& $5.0-8.0$ & Moderately damp wall \\
& $8.0-12.0$ & Very damp wall \\
& $>12.0$ & Wet wall \\
Salinity classification & $<0.2$ & \\
Chlorides $\left(\mathrm{Cl}^{-}\right)$in $\%$ & $0.2-0.5$ & Low \\
& $>0.5$ & Average \\
& $<0.1$ & High \\
Nitrates $\left(\mathrm{NO}_{3}^{-}\right)$in $\%$ & $0.1-0.3$ & Low \\
& $>0.3$ & Average \\
Sulphates $\left(\mathrm{SO}_{4}{ }^{2-}\right)$ in $\%$ & $<0.5$ & High \\
& $0.5-1.5$ & Low \\
& $>1.5$ & Average \\
& & High \\
\hline
\end{tabular}

protection against moisture and its implementation, and controlling the effectiveness of the conducted protection in later periods. They should also be the basis for making such decisions as the necessity or not to get rid of the salts that are harmful to the wall, the choice of an artificial or natural way to dry the damp wall, estimating the time and costs of such drying, etc.

For the tests of the moisture content to be reliable and the decisions based on them to be accurate, they cannot be cursory and fragmentary, but instead must be comprehensive and methodical. What is more, they cannot be conducted without the awareness of the limitations of the apparatus that was used in the research [8], which is also often the case. However, there is no such methodology described in literature. In turn, the literature review shows that, although some papers indicate selected recommendations and guidelines for conducting moisture tests [e.g. [6, 10-12], a consistent test methodology is not obtained even after collecting them together. The consequences of this are numerous cases of inaccurate decisions, which are based on incomplete and not very reliable tests. Due to this, there are actions that not only do not fully solve the problem of excessive moisture and salinity of brick walls, but also lead to unjustified costs.

Considering the above, the purpose of this article-after briefly highlighting the causes and negative effects of excessive moisture and salinity-is to present an original methodology for testing the moisture content of brick walls, which was developed on the basis of our own experience acquired 
when testing the moisture content in many buildings erected in different historical periods. This methodology was enriched by the correlative relations between the mass moisture content and a dimensionless parameter that was measured using various non-destructive methods on walls erected in different historical periods. They were included in the article, and thus made available to other researchers. In addition, the article is illustrated using an example of the effects of the moisture content tests that were carried out according to the developed methodology on a brick building from the fourteenth century.

The structure of the article is as follows: point 1 is an introduction to the issues, in point 2 , the causes and effects of excessive moisture are presented, point 3 presents and discusses the developed research methodology, while point 4 contains an example of the application of the developed methodology. The last part of the paper contains the summary.

\section{Causes and effects of excessive moisture}

The moisture content of a brick wall is determined by the amount of water-physically and mechanically bound and unbound - that penetrates deep into the wall, which is mainly due to capillary rising or as a result of condensation. Moisture caused by capillary rising occurs when a building's walls were not protected against moisture, i.e. when horizontal and vertical damp-proof insulation was not made, or was made incorrectly. Due to this, the wall is moistened with the water contained in the ground. The mechanism of the transport of moisture in capillary-porous materials is known, and was described, among others, in [13-15]. However, it should be mentioned at this point that capillary rising is a phenomenon that occurs in hydrophilic materials that are characterized by pores, whose radii are in the range of $10^{-2}-10^{-3} \mathrm{~mm}[13,15]$. These are the dominant components of a brick wall. The height of capillary ascending moisture depends to a large extent on the radius of the capillary pores - the smaller the radius, the bigger the rising height [15]. For example, in historical buildings, such moisture may even reach a few meters above the level at which the wall is in direct contact with the ground [10].

Water from the long-term condensation of water vapor on internal surfaces or inside a wall also contributes to excessive moisture. This is caused by an insufficient thermal insulation of a partition. In addition, moisture is compounded by crystallized salts that are present in a wall, which hygroscopically absorb moisture from the surrounding air. Figure 2 illustrates how significant the increase in the moisture content of a brick wall can be because of this.

An important effect of excessive moisture, from the point of view of safety of the building structure, is a reduction of

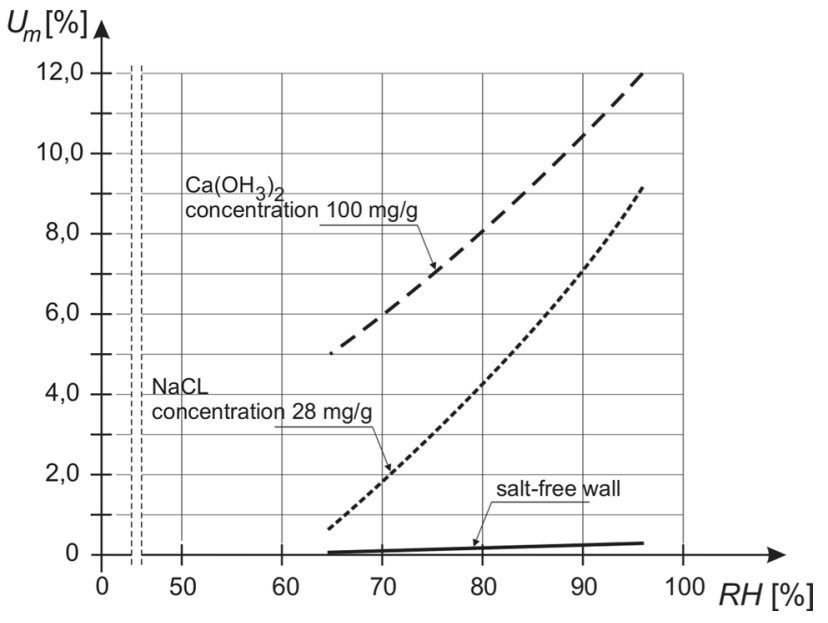

Fig. 2 An increase in the mass moisture content of a brick wall caused by the sorption of moisture from the air with regards to the relative moisture content and the type and concentration of salts in the wall [16]

the mechanical strength of the wall components, which can lead to its deformation and cracks. It should be mentioned that the decrease in the compressive strength of porous materials due to an increase in moisture may also occur as a result of typically physical interactions such as brittle damage due to tensile shrinkage stress, softening of the material structure due to action of disjoining pressure or Rebinder's effect. It is expected especially in mortar, and it also increases its ability to plastic deformation and creep [17]. Figure 3 shows a diagram that illustrates the gradual change in the compressive strength of a brick wall due to changes in its moisture condition over time. This figure was made while assuming that there was no frost destruction of the wall.

The negative effects of excessive moisture, which involve a reduction of the mechanical strength of a wall, are compounded by the destructive effect of the above-mentioned water-soluble salts, which, as a result of crystallization and hydration processes, occur in the subsurface zone of the wall and on its surface. In these places, the drying process is the most intense, which causes damage to the wall's structure and the forming of surface salt efflorescence [18-20]. Figure 4 illustrates this mechanism.

The salts in question, mainly sulphates, chlorides, nitrates and carbonates, are ubiquitous in the environment that surrounds buildings. Their origin is partly natural, and partly a result of human activities that cause environmental pollution, e.g. fertilizing soils with artificial fertilizers, or using chemical plant protection products $[12,20]$.

Excessive moisture of the wall also negatively affects the thermal properties of the materials it is built of. It increases the heat transfer coefficient $U$ of a partition, and thus reduces thermal insulation, which is particularly unfavourable with regards to external partitions [21]. The illustration of the above 
Fig. 3 Diagram illustrating a gradual change in the compressive strength of a wall due to changes in its moisture condition over time [17]

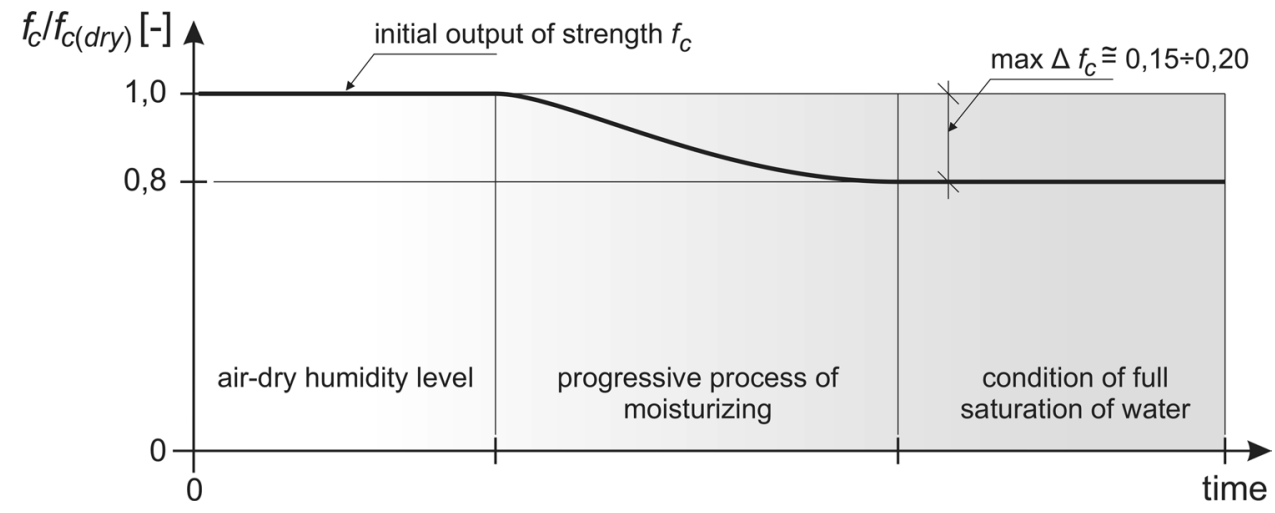

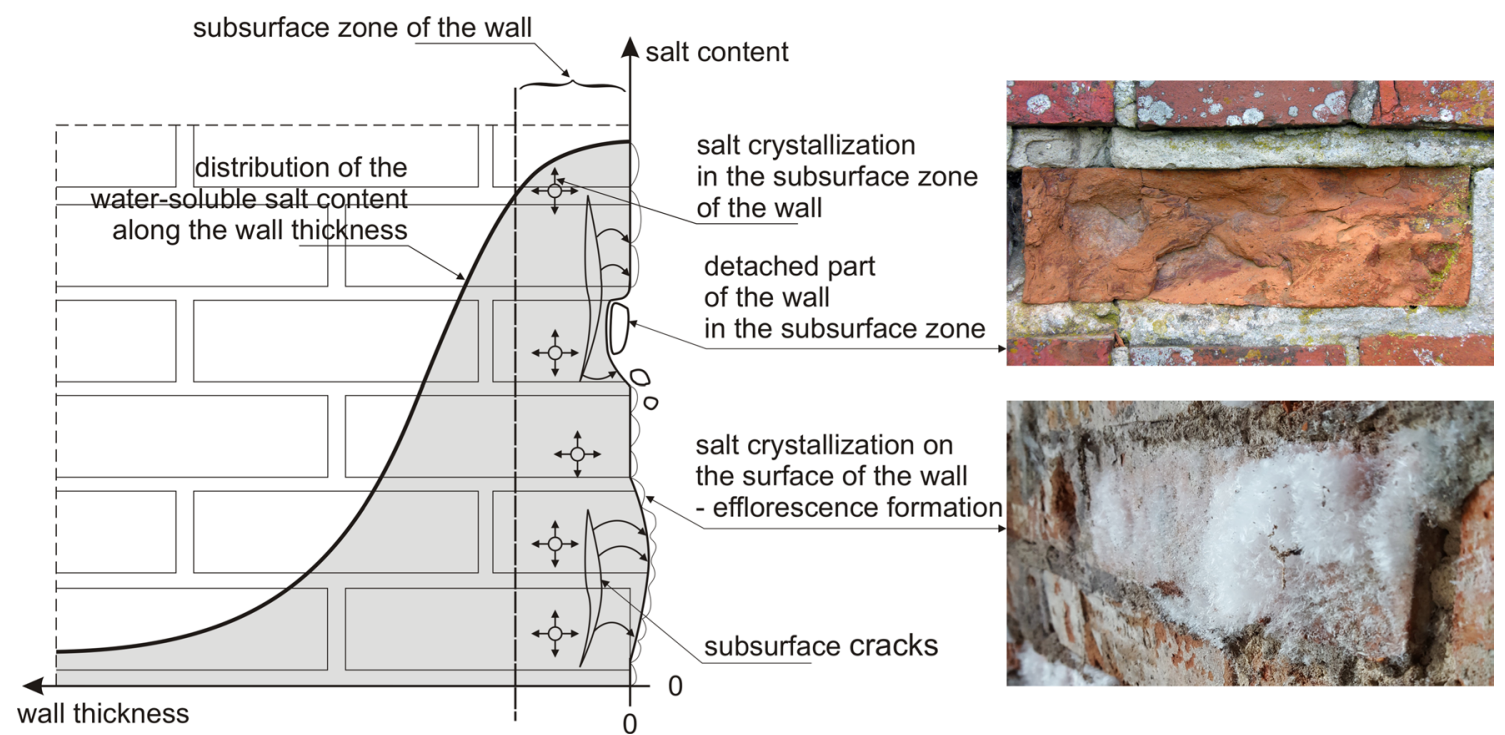

Fig. 4 Typical distribution of the water-soluble salt content along the wall thickness, and also the mechanism of wall destruction in the subsurface zone [9]

statement can be seen in Fig. 5a, which, as was the case in [16, 22], shows the impact of the moisture content on the thermal conductivity of the ceramic brick that was used to construct the walls. It can also be seen in Fig. 5b, which illustrates the effect of the increase in the mass moisture content of the wall on the reduction of thermal insulation.

The consequence of the deterioration of the thermal properties of a partition, which was caused by an excessive moisture content, is the deterioration of the operating conditions in rooms. This is not only manifested by steam that condenses on the internal surface of a partition, but also by the development of mold and domestic fungi, which are harmful to human health [23].

\section{Research methodology}

The developed methodology for conducting in situ brick wall moisture content testing is graphically presented in Fig. 6 and described below.

The starting point for the research in question should be an analysis of the available technical documentation of the facility, which is supported by a visual inspection. On this basis, a preliminary picture of the situation is obtained, as well as knowledge about whether an object is under conservation protection. This knowledge is important, because it largely determines further activities on site, and 


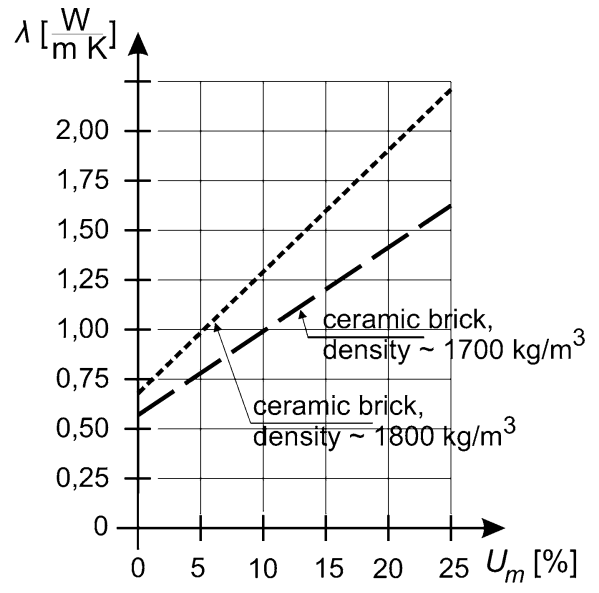

(a)

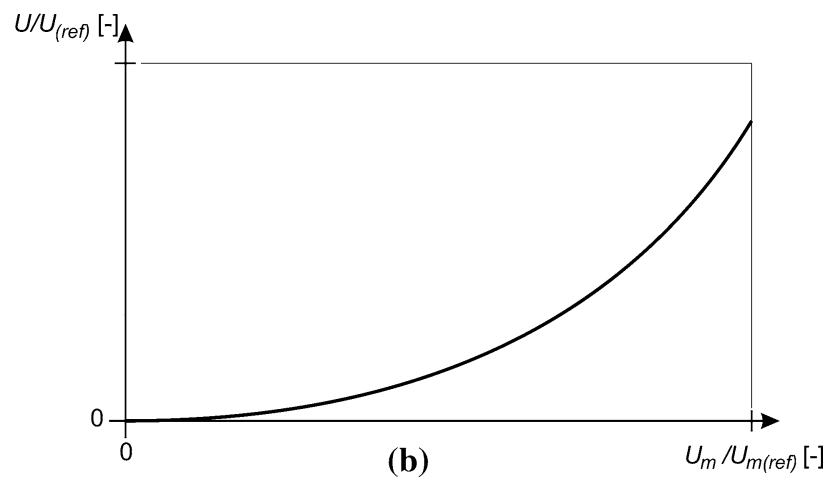

Fig. 5 a The influence of the moisture content on the thermal conductivity $\lambda$ of ceramic brick [16, 22]; $\mathbf{b}$ dependence between the mass moisture content of the wall $U_{\mathrm{m}}$ and the heat transfer coefficient $U$ of the wall

in particular, affects the choice of test method. Currently, various test methods, both destructive and non-destructive, are predestined to conduct tests of the moisture content in brick walls. They were presented in the form of a diagram and described in detail in [8]. For the purpose of this paper, however, it should be recalled that destructive methods require the sampling of a material for testing, while non-destructive methods do not require interference with the structure of an object. Therefore, if the object is not subjected to conservation protection, there is a free choice from all the available methods. Otherwise, only tests using non-destructive methods can be conducted. Out of these methods, dielectric and microwave methods, as well as the electrical resistivity method (with some limitations) seem to be most useful for testing brick wall moisture [8]. It is worth pointing out that the group of the abovementioned test methods may soon be expanded with a new method using both impedance tomography and capacitive tomography for spatial analysis of the moisture content of walls. The prototype of the hybrid tomograph has already been constructed and tested in laboratory conditions close to real and in real conditions as well [24-26]. However, according to the authors of the indicated works further research is needed to create a compact portable device.

The next step, after choosing the testing method, is to conduct tests and to obtain reliable results. Depending on whether a destructive or non-destructive method was chosen, the procedure will be different.

In the case of conducting tests using the destructive method, first of all, the $k$ number of places should be selected for masonry sampling in order to determine in a laboratory their mass moisture content $U_{\mathrm{m}}$, and the type and concentration of salts that are present in them. To obtain a reliable picture of the state of the moisture content-and thus the value of the moisture content and its distribution in the wall-sampling points cannot be arranged accidentally, but instead regularly and while forming a grid of points. They should be spaced at relatively even intervals along the perimeter of the walls, and at several heights above the floor level. Only then will it be possible to develop (after obtaining the test results) the moisture content profiles at a height, along the thickness, and along the perimeter of the walls. The next step involves taking samples-in selected places, and also on the thickness of the wall-and delivering them in hermetic containers to the laboratory, where the mass moisture content $U_{\mathrm{m}}$ of the specimens and the type and concentration of salts that are harmful for the wall must be determined experimentally. To collect samples from the inside of the wall drilling is done with the use of the lace drill or standard drill, and then samples are taken with a chisel. During sampling, particular attention should be paid to do not dry the sample with heat generated during drilling. That is why drills are most often used impact slow speed [6].

In the case of choosing a non-destructive method, the number of $m$ places for measurements needs to first be selected. The guidelines that are described above should be followed. Afterwards, from $m$ places, $n$ places for taking masonry specimens should be chosen in order to determine, in a laboratory, the type and concentration of salts, and also the mass moisture content $U_{\mathrm{m}}$. This is required for scaling the apparatus when using non-destructive testing. Samples should be taken at different heights above floor level, so that they represent the widest possible range of humidity values. If a facility is under conservation protection, the planned scope of tests should be consulted with conservation services before commencing, and if necessary corrected.

It should be clarified that scaling of non-destructive testing apparatus on the tested object is essential. As standard, meters are scaled by the manufacturer in laboratory conditions. Meanwhile, the meter indications depend not only on the moisture content but also on other characteristics of the material being tested, e.g. the type and concentration of salts, which are characteristic for a particular object. Therefore, in order to increase the accuracy 


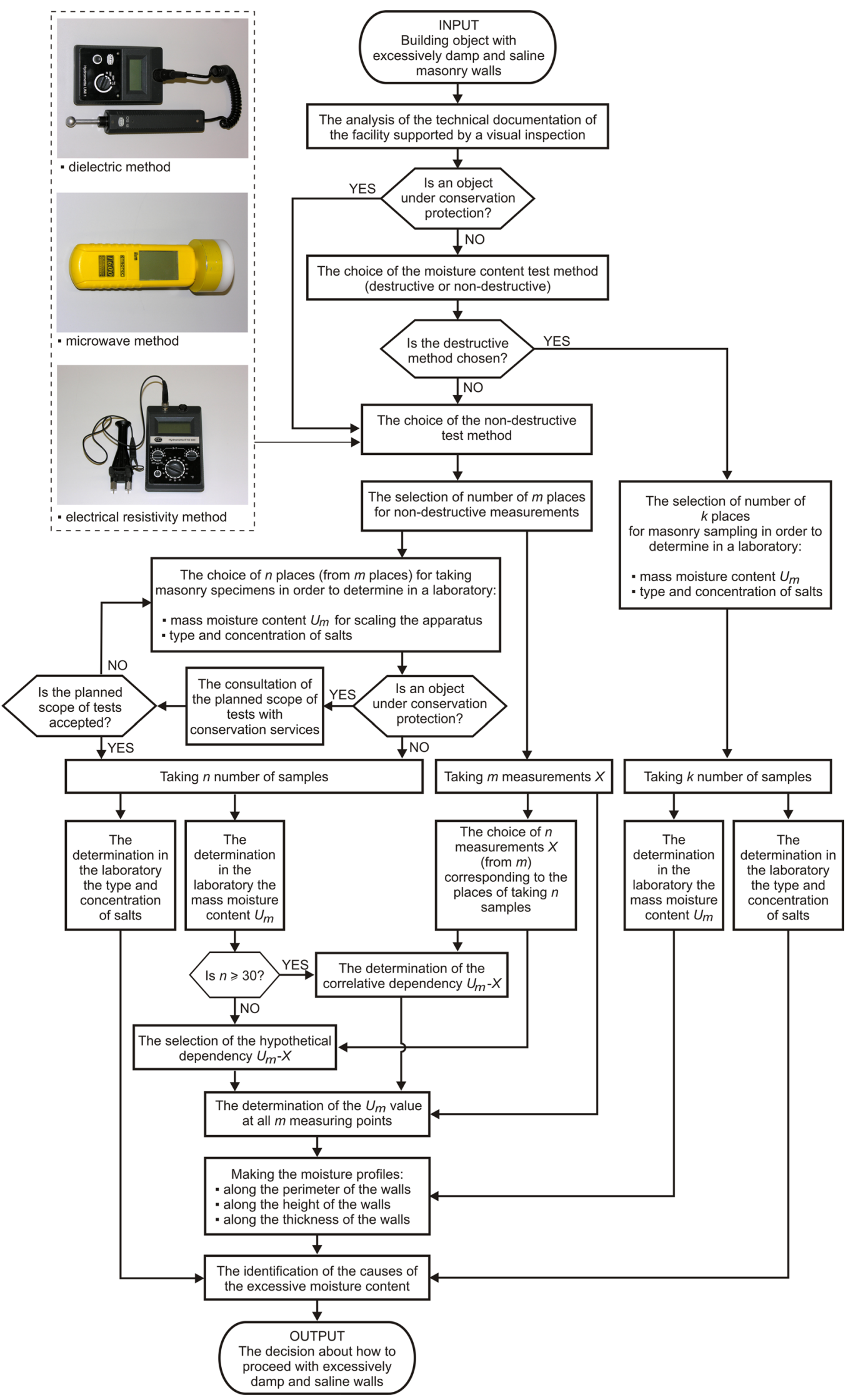

Fig. 6 Methodology for testing the mass moisture content of brick walls 
of measurements, on the basis of pairs of results ( $X$-indication of the meter, $U_{\mathrm{m}}$-mass moisture determined by the gravimetric method), the appropriate scaling curve for given meter and material should be chosen from among hypothetical curves that are available in the literature. This procedure has been precisely discussed in [6].

The next step after selecting $m$ places for measurements and $n$ places for taking masonry specimens for scaling the apparatus involves the conducting of tests, i.e. taking $m$ measurements and taking $n$ samples. The number of the latter ones ( $n$ samples) is agreed upon with the conservation services and determines further actions. If $n$ is in the range of $\langle 6 ; 30\rangle$, a hypothetical curve from those available in the literature needs to be selected, as it has been already mentioned before. However, if $n$ is equal to, or greater than 30, the correlative relationship is determined based on the $U_{\mathrm{m}}-X$ pair of results. This regularity is shown in Fig. 7. Then, hypothetical and correlative curves allow the $U_{\mathrm{m}}$ value to be determined at all $m$ measuring points.

To satisfy those interested in this issue, Table 3 presents exemplary correlative dependencies $U_{\mathrm{m}}-X$ for the non-destructive dielectric, microwave, and electrical resistivity methods, which were determined during the authors' own research conducted on wet and saline masonry walls in buildings erected in different periods-from the thirteenth century to the twentieth century; some of these relationships, however, have not yet been published [27-30]. The table also contains correlative relationships that were determined in laboratory conditions for walls made of the currently produced bricks and mortar [31].

Afterwards, based on the results of tests obtained using the non-destructive or destructive methods, moisture profiles should be made along the perimeter of the walls, as well as along their height and thickness. These profiles, together with the results of salinity tests, are very useful for the correct identification of the causes of moisture content, and thus for making decisions about how to proceed with excessively damp and saline walls.

\section{An example of the application of the developed methodology}

The methodology presented in this article was used to carry out tests of the moisture content in brick walls of rooms located in the underground of a Gothic monastery that is dated from the turn of the thirteenth and fourteenth centuries. These rooms have walls made of solid ceramic brick with lime mortar, and their thickness is in the range of $60-180 \mathrm{~cm}$. The walls are covered with brick barrel and cross-rib vaults.

The building is historic, and therefore the non-destructive dielectric method with the use of the Gann Uni 2 m, and also the microwave method using the Trotec T600 meter were selected for the tests. They were supplemented with the destructive gravimetric method, which was used for scaling the apparatus. Afterwards, the measuring points and places for taking wall samples were selected. Due to the poor technical condition of the basement walls, conservation services agreed to interfering with historical tissue to the extent that was necessary to obtain the most reliable test results. In total, 74 samples with an average weight of about $50 \mathrm{~g}$ were taken with a low speed drill. The number of samples enabled two correlative dependencies, which were representative for individual research methods and for the tested wall, to be determined. They are listed in Table 3 (item 1).

Regular distribution of measuring points on the surfaces of walls enabled the moisture content profiles along the length and at the height of individual walls, as well as on several levels above the floor, to be prepared. The moisture content of walls in historic buildings usually reaches well above the level at which these walls are in direct contact with the ground. Therefore, to determine how high the moisture content in the tested building is, the measurements of the moisture content were also conducted at the level of the ground floor in rooms located above the tested basement rooms. The distribution of the mass moisture content $U_{\mathrm{m}}$ along the thickness $d$ of the wall was determined, both at the underground and ground level, using the gravimetric
Fig. 7 Methods for determining the relationship $U_{\mathrm{m}}-X$ for the non-destructive dielectric or microwave methods used in the tests [8]

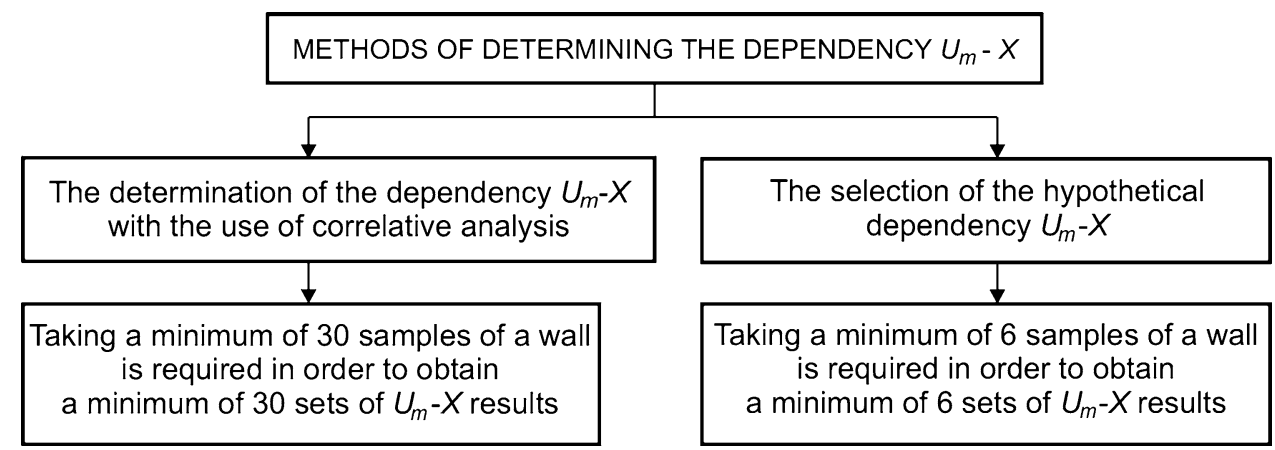


Table 3 Exemplary correlative dependencies of $U_{\mathrm{m}}-X$ for brick walls erected in different periods, which were determined using non-destructive dielectric, microwave, and electrical resistivity methods during the authors' own tests, as well as on the basis of available laboratory test results

\begin{tabular}{|c|c|c|c|c|c|}
\hline \multirow[t]{2}{*}{ No } & \multirow[t]{2}{*}{ Time of erecting the wall } & \multicolumn{3}{|c|}{ Physical parameters of brick } & \multirow[t]{2}{*}{ Correlative dependency $U_{\mathrm{m}}-X$} \\
\hline & & Density $\left[\mathrm{g} / \mathrm{cm}^{3}\right]$ & Bulk density $\left[\mathrm{g} / \mathrm{cm}^{3}\right]$ & Total porosity $[\%]$ & \\
\hline 1 & XIII/XIV century & 2.70 & 1.78 & 33.98 & $\begin{array}{l}\text { Dielectric method (Gann Hydromette Uni } 2 \mathrm{~m}): U_{\mathrm{m}} \\
\quad=1.665 \mathrm{e}^{0.035 X} ; R^{2}=0.83 ; \text { no of samples: } 74 ; X \\
\quad \mathrm{X}<15.2 ; 86.1>[27.28] \\
\text { microwave method (Trotec T } 600 \mathrm{~m}) \text { : } \\
U_{\mathrm{m}}=0.0003 X^{2.566} ; \mathrm{R}^{2}=0.93 ; \text { no of samples: } 74 ; \\
\quad X \mathrm{X}<20.1 ; 141.0>[27]\end{array}$ \\
\hline 2 & $\mathrm{XIV} / \mathrm{XV}$ century & - & - & - & $\begin{array}{l}\text { Dielectric method (Gann Hydrmette Uni } 2 \mathrm{~m} \text { ): } \\
U_{\mathrm{m}}=0.81 \cdot 1.015^{X} ; R^{2}=0.96 ; \text { no of samples: } 30 \\
X \mathrm{X}<40.0 ; 100.0>[29.30] \\
U_{\mathrm{m}}=0.07 \cdot 1.04^{X} ; \mathrm{R}^{2}=0.94 ; \text { no of samples: } 30 \\
X \mathrm{X}<100.0 ; 140.0>[29.30]\end{array}$ \\
\hline 3 & XVI-XIX century & - & - & - & $\begin{array}{l}\text { Dielectric method (Gann Hydromette Uni } 2 \mathrm{~m}) \text { : } \\
\quad U_{\mathrm{m}}=0.6601 \mathrm{e}^{0.0218 X} ; R^{2}=0.80 ; \text { no of samples: } 30 \\
X \mathrm{X}<40.0 ; 144.7> \\
\text { microwave method (Trotec T } 600 \mathrm{~m}) \text { : } \\
U m=0.3196 X-6.4287 ; \mathrm{R}^{2}=0.84 ; \text { no of samples: } \\
\quad 33 ; X \mathrm{X}<23.5 ; 76.0>\end{array}$ \\
\hline 4 & End of XIX century & $2.67 \div 2.71$ & $1.82 \div 1.86$ & $30.97 \div 31.48$ & $\begin{array}{l}\text { Electrical resistivity method (Gann Hydromette } \\
\text { RTU } 600 \mathrm{~m}): U_{\mathrm{m}}=0.0028 X^{2}-0.0531 X+1.4538 ; \\
R^{2}=0.81 ; \text { no of samples: } 30 ; X \mathrm{X}<23.2 ; 83.4> \\
\text { Dielectric method (Gann Hydromette Uni } 2 \mathrm{~m}) \\
U_{\mathrm{m}}=0.5945 \mathrm{e}^{0.0173 X} ; R^{2}=0.80 ; \text { no of samples: } 30 ; \\
X \mathrm{X}<41.3 ; 141.9> \\
U_{\mathrm{m}}=0.3581 e^{0.0233 X} ; \mathrm{R}^{2}=0.81 ; \text { no of samples: } 30 ; \\
X \mathrm{X}<39.8 ; 147.5> \\
U_{\mathrm{m}}=0.6013 \mathrm{e}^{0.0216 X} ; R^{2}=0.81 ; \text { no of samples: } 30 ; \\
X \mathrm{X}<35.0 ; 140.0> \\
\text { Microwave method (Trotec } \mathrm{T} 600 \mathrm{~m}): \\
U_{\mathrm{m}}=0.1425 X-1.7753 ; R^{2}=0.80 ; \text { no of samples: } \\
30 ; X \mathrm{X}<20.5 ; 74.0> \\
U_{\mathrm{m}}=0.193 X-3.5015 ; R^{2}=0.82 ; \text { no of samples: } \\
30 ; X \mathrm{X}<30.6 ; 79.2>\end{array}$ \\
\hline 5 & XXI century & $2.53 \div 2.65$ & $1.99 \div 1.75$ & $21.38 \div 33.96$ & $\begin{array}{l}\text { Dielectric method }(\text { Gann Hydromette Uni } 2 \mathrm{~m}): U_{\mathrm{m}} \\
\quad=0.00011 \mathrm{e}^{0.0413 X} ; R^{2}=0.85 ; \text { no of samples: } 48 ; \\
X \mathrm{X}<73.0 ; 160.9>[31] \\
\text { Microwave method (Trotec T } 600 \mathrm{~m}) \text { : } \\
U_{\mathrm{m}}=0.0017 X-0.0416 ; R^{2}=0.86 ; \text { no of samples: } \\
\quad 48 ; X \mathrm{X}<26.6 ; 70.4>[31] \\
\text { Electrical resistivity method (Gann Hydromette } \\
\text { RTU } 600 \mathrm{~m}): U_{\mathrm{m}}=0.0013 X ; R^{2}=0.92 ; \text { no of } \\
\text { samples: } 72 ; X \mathrm{X}<1.7 ; 75.2>[32]\end{array}$ \\
\hline
\end{tabular}

method. Examples of test results are presented in Figs. 8, 9, 10 and 11.

The basic physical characteristics of the ceramic brick from which the basement walls are constructed were also determined experimentally. The wall's samples were taken from several different places, and the results of the conducted tests are presented in Table 4. It was found that the total porosity of the brick is very high and amounts to almost $34 \%$. When comparing this result with the high mass moisture content of the wall, both in the subsurface zone and in the middle of the wall's thickness, it was found that the degree of filling the pores with water is very high and-depending on the considered zone of the wallreaches from about $60 \%$ to about $90 \%$.

In addition, the type of salts and their concentration were tested in more than 40 places using the semi-quantitative method. They showed that there are harmful salts in the form of chlorides and sulphates in the basement walls (Table 5); however, according to the classification adopted in the technical literature that is given in Table 1 of this paper, this salinity is low.

After analysing the test results, the causes of the excessive moisture in the basement brick walls of the monastery were determined. The main reason was seen to be 


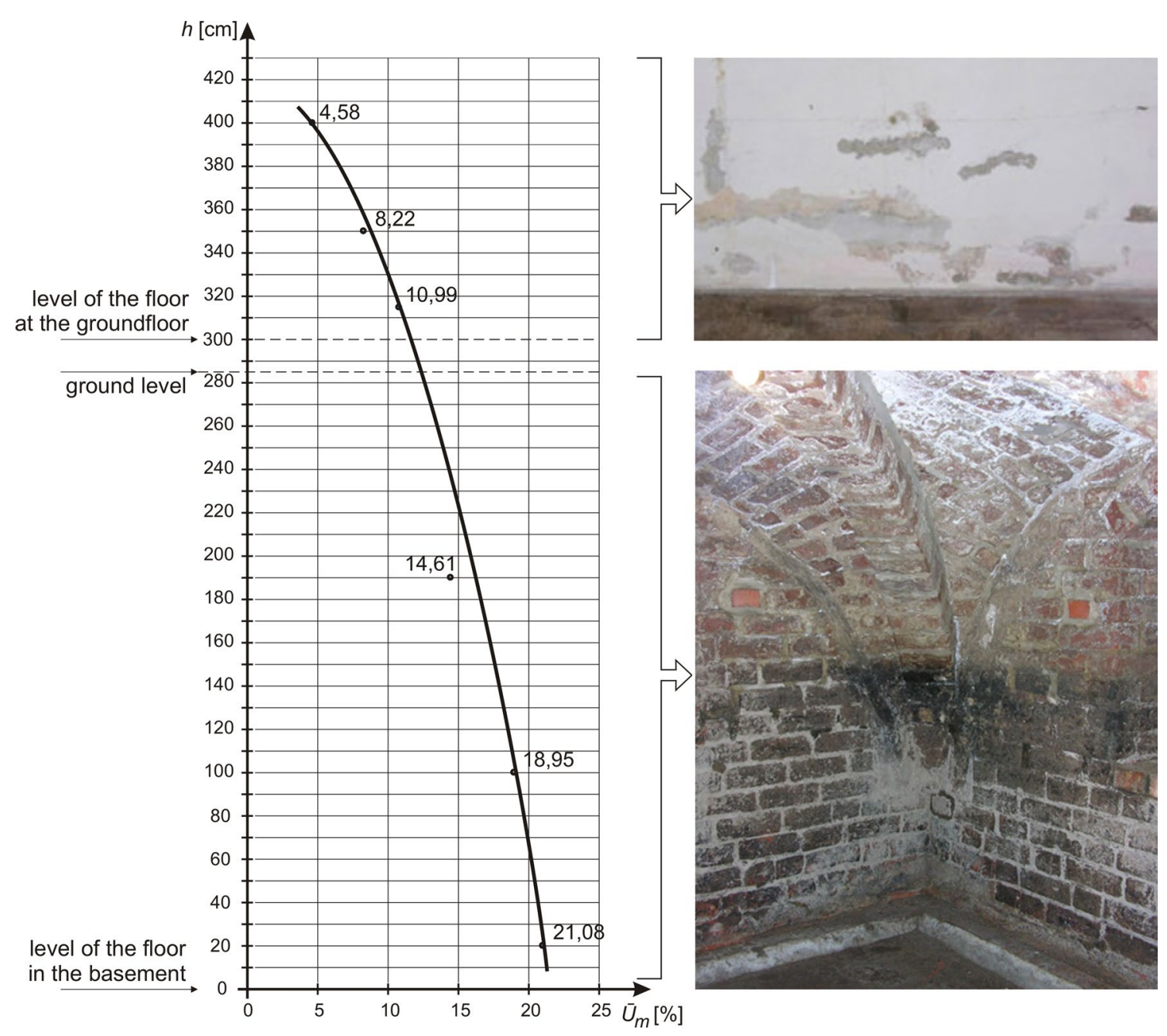

Fig. 8 An exemplary average distribution of the mass moisture content $\bar{U}_{\mathrm{m}}$ at the height of the masonry underground walls, and also above ground in the subsurface zone, which was prepared on the basis of the results obtained using the dielectric method

the capillary rising of water from the ground due to the lack of horizontal damp-proof insulation. This process was intensified by the evaporation of moisture from wet walls and floors, which, in the absence of effective ventilation of the rooms, caused a secondary moistening of these partitions. It was also found that the dampness of the walls was aided by lateral capillary rising of water from the ground through the wall as a result of a lack of vertical damp-proof insulation of the walls.

The results of the conducted tests became the basis for calculating the amount of water contained in the wall that should be drained from it, choosing the method and specifying the costs of draining this moisture, determining the duration of this process, and making a decision about how to protect the walls of the building against moisture.

\section{Summary}

The article presents original methodology for testing the moisture content in the brick walls of masonry buildings. It was developed on the basis of own experience acquired during moisture content tests that were conducted in many excessively damp buildings erected in various historical periods. There is a lack of such a methodology in literature, while at the same time, knowledge concerning it and its application makes it possible to conduct research in a consistent and comprehensive manner. In this context, it seems particularly important to not only determine the moisture content, but also its distribution in a wall. Therefore, it is important to distribute measuring points 

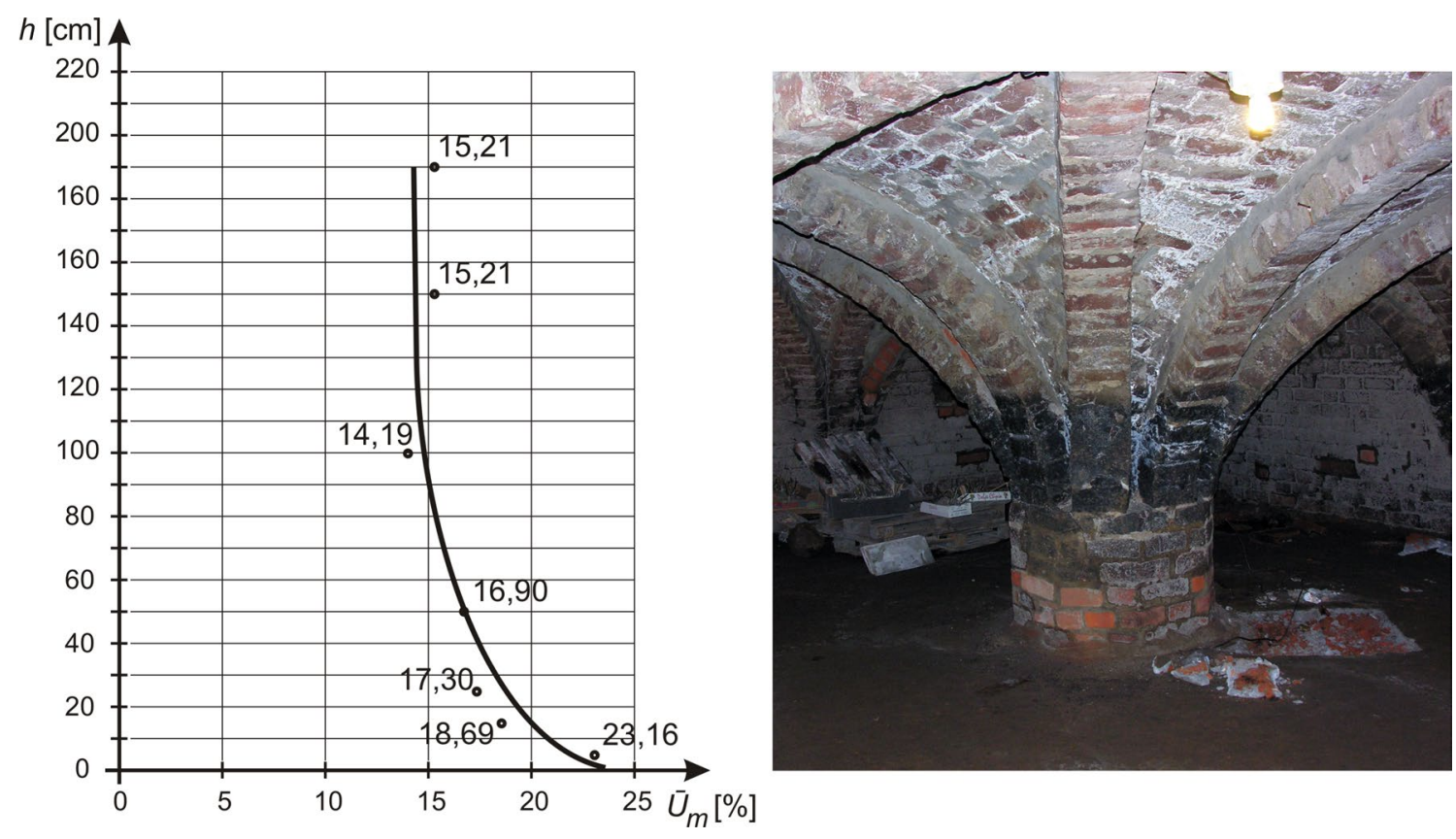

Fig. 9 An exemplary average distribution (profile) of the mass moisture content $\bar{U}_{\mathrm{m}}$ at the height of a brick pillar and a vault in the subsurface zone, which was prepared on the basis of the results obtained using the dielectric method

regularly, which will enable the moisture content profiles along the length and at the height of individual walls, as well as on several levels above the floor, to be prepared.

According to the author, the improvement of the quality of the conducted tests, as a result of using the presented methodology, should increase the credibility of the obtained results which are the basis for making correct decisions regarding further handling of wet walls. These are primarily the choice of the optimal method of moisture protection for a given situation, as well as its implementation, and controlling the effectiveness of the protection performed. Other decisions include monitoring the effectiveness of protection, making decisions about getting rid of harmful salts, choosing an artificial or natural way of drying a damp wall, estimating the time and cost of such drying.
The article contains the correlative dependencies-those developed by the author and those available in the literature-between the mass moisture content and the dimensionless parameter that was measured using various nondestructive methods for walls erected in different historical periods. They can be used by other researchers, especially when examining historic buildings. In such a case, interference in the historical tissue is usually very limited due to the restrictions of the conservation services.

An overview of the methodology was preceded by a brief description of the causes and negative effects of excessive moisture and salinity in brick walls. In addition, the article is illustrated with an example of the effects of moisture content tests that were carried out according to the developed methodology on a fourteenth century facility. 


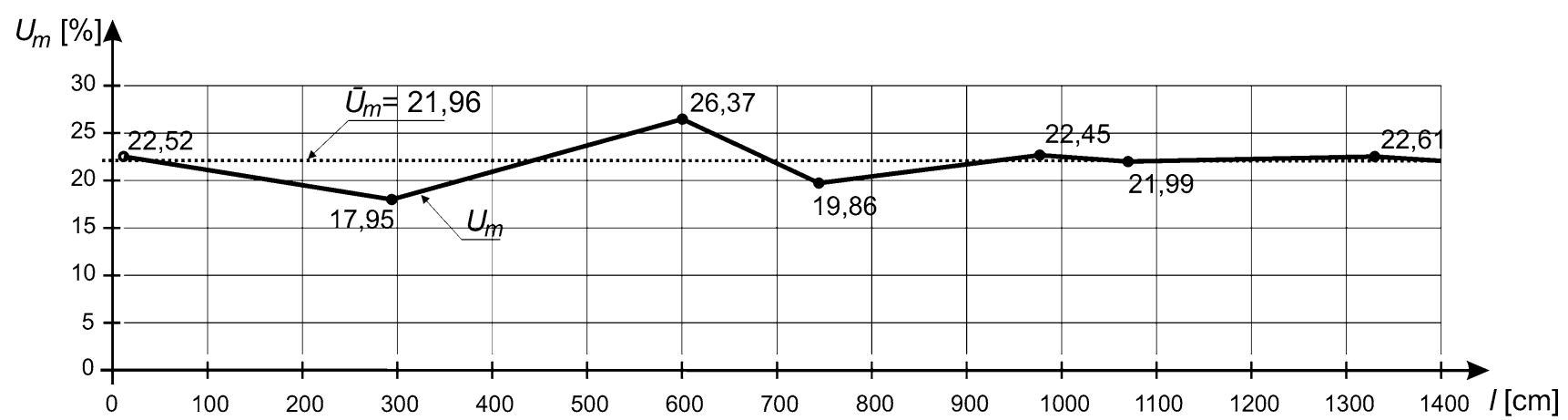

(a)

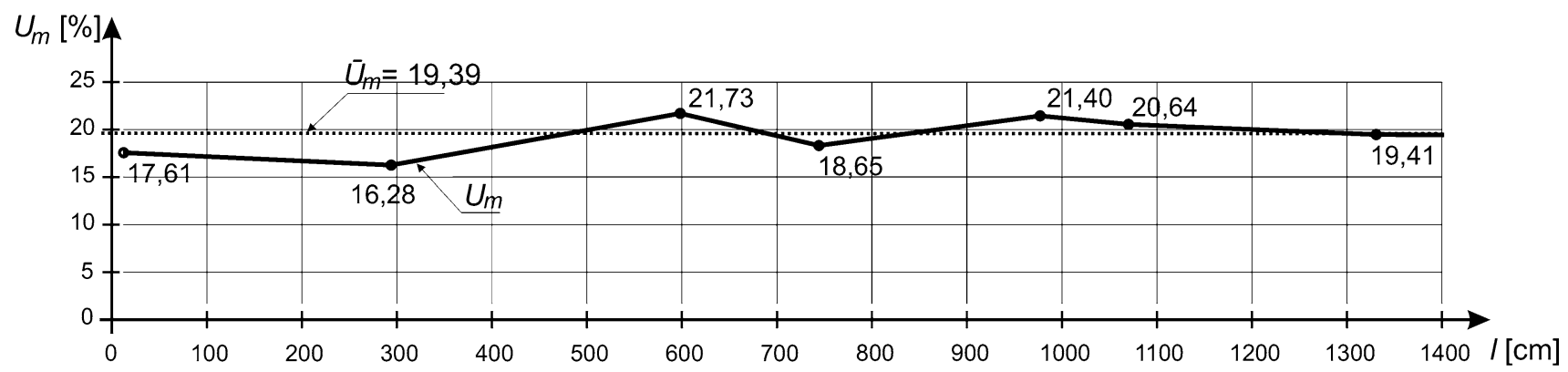

(b)

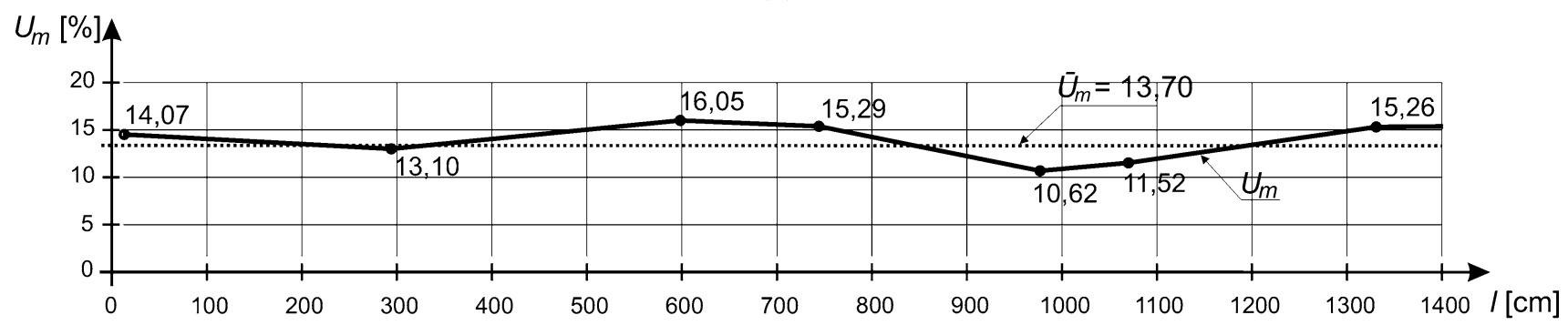

(c)

Fig. 10 Exemplary profiles of the mass moisture content $U_{\mathrm{m}}$ along the length of one of the basement's walls, which were prepared on the basis of test results that were obtained using the microwave method: a a a height of $20 \mathrm{~cm}$ above the floor; $\mathbf{b}$ at a height of $100 \mathrm{~cm}$ above the floor; $\mathbf{c}$ at a height of $180 \mathrm{~cm}$ above the floor
Fig. 11 Distribution of the mass moisture content $U_{\mathrm{m}}$ along the thickness of one of the external basement walls at a height of about $50 \mathrm{~cm}$ above the floor, which was prepared on the basis of results obtained using the gravimetric method

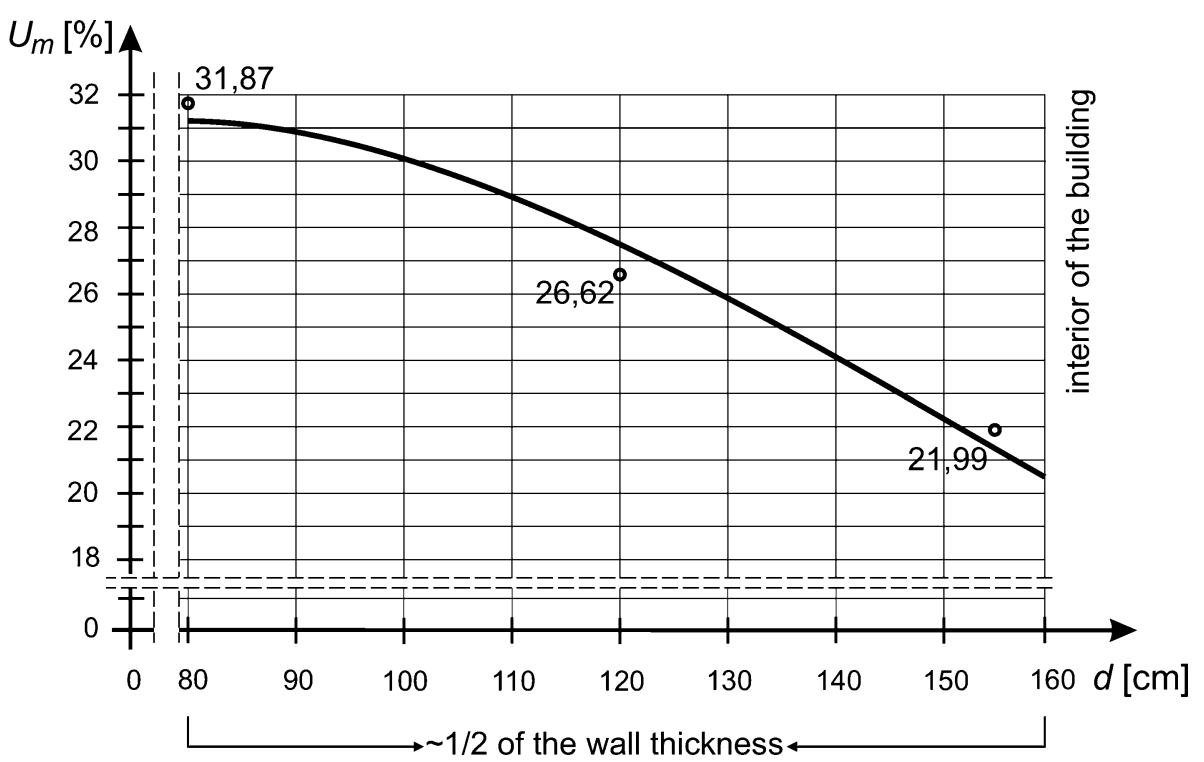


Table 4 The results of testing the physical characteristics of the brick

\begin{tabular}{llllll}
\hline Sample designation & Density $\left(\mathrm{g} / \mathrm{cm}^{3}\right)$ & $\begin{array}{l}\text { Bulk } \\
\text { density }(\mathrm{g} / \\
\left.\mathrm{cm}^{3}\right)\end{array}$ & Absorptivity (\%) & Total porosity (\%) & Tightness (\%) \\
\hline $\mathrm{A}$ & 2.71 & 1.79 & 17.32 & 33.95 & 66.05 \\
$\mathrm{~B}$ & 2.70 & 1.78 & 17.15 & 34.07 & 65.93 \\
$\mathrm{C}$ & 2.69 & 1.77 & 17.95 & 34.02 & 65.80 \\
$\mathrm{D}$ & 2.70 & 1.79 & 17.44 & 33.70 & 66.30 \\
Mean value & 2.700 & 1.783 & 17.465 & 33.980 & 66.02 \\
\hline
\end{tabular}

Table 5 The results of tests of the type and concentration of salts contained in the basement walls

\begin{tabular}{llll}
\hline Type of salts & Value range $(\%)$ & Mean value $(\%)$ & $\begin{array}{l}\text { Classification of the salinity of } \\
\text { the tested brick walls according to } \\
{[7-9]}\end{array}$ \\
\hline Chlorides & $0.011 \div 0.040$ & 0.020 & Low or average \\
Sulphates & $0.200 \div 0.300$ & 0.222 & Low \\
Nitrates & $0.000 \div 0.025$ & 0.002 & Low \\
\hline
\end{tabular}

Open Access This article is licensed under a Creative Commons Attribution 4.0 International License, which permits use, sharing, adaptation, distribution and reproduction in any medium or format, as long as you give appropriate credit to the original author(s) and the source, provide a link to the Creative Commons licence, and indicate if changes were made. The images or other third party material in this article are included in the article's Creative Commons licence, unless indicated otherwise in a credit line to the material. If material is not included in the article's Creative Commons licence and your intended use is not permitted by statutory regulation or exceeds the permitted use, you will need to obtain permission directly from the copyright holder. To view a copy of this licence, visit http://creativecommons.org/licenses/by/4.0/.

\section{References}

1. Ruiz VL, Flores SV, Prieto VE. In situ assessment of superficial moisture condition in facades of historic building using nondestructive techniques. Case Stud Constr Mater. 2019;10:e00228.

2. Freimanis R, Vaiskunaite R, Bezrucko T, Blumberga A. Insitu moisture assessment in external walls of historic building using non-destructive methods. Environ Clim Technol. 2019;23(1):122-34.

3. Lubelli B, van Hees RPJ, Groot CWP. Investigation on the behaviour of a restoration plaster applied on heavy salt loaded masonry. Constr Build Mater. 2006;20:691-9.

4. Ince I, Bozdag A, Tosunlar MB, Hatir ME, Korkanc M. Determination of deterioration of the main façade of the Ferit Pasa Cistern by non-destructive techniques (Konya, Turkey). Environ Earth Sci. 2018;77(1):420

5. Falchi L, Slanzi D, Balliana E, Driussi G, Zendri E. Rising damp in historical buildings: a venetian perspective. Build Environ. 2018;131:117-27.

6. Jasieńko J, Matkowski Z. Zasolenie i zawilgocenie murów ceglanych w obiektach zabytkowych - diagnostyka, metodyka badań, techniki rehabilitacji. Wiadomości Konserwatorskie. $2003 ; 14: 43-8$.
7. WTA 2-6-99-D. Erganzungen zum WTA-Merkblatt 2-2-91-D. Sanierputzsysteme. 1991.

8. Hoła A. Measuring of the moisture content in brick walls of historical buildings the overview of methods. In: 3rd International Conference on innovative materials, structures and technologies 2017; https://doi.org/https://doi.org/10.1088/1757-899X/251/1/012067

9. Goetzke-Pala A, Hoła A, Sadowski Ł. A non-destructive method of the evaluation of the moisture in saline brick walls using artificial neural networks. Arch Civ Mech Eng. 2018;18:1729-42.

10. Adamowski J, Hoła J, Matkowski Z. Probleme und Lösungen beim Feuchtigkeitsschutz des Mauerwerks von Baudenkmälern am Beispiel zweier grosser Barockbauten in Wrocław. Bautechnik. 2005;82:426-33.

11. Franzoni E. Rising damp removal from historical mansonries: a still open challenge. Constr Build Mater. 2014;54:123-36.

12. Rokiel M. Hydroizolacje w budownictwie. Warszawa: Grupa MEDIUM; 2006.

13. Kubik J. Przepływ wilgoci w materiałach budowlanych. Opole: Oficyna Wydawnicza Politechniki Opolskiej; 2000.

14. Raimondo M, Dondi M, Guardini G, Mazzanti F. Predicting the initial rate of water absorption in clay brick. Constr Build Mater. 2009;23:2623-30.

15. Alsabry A. Dynamika podciągania kapilarnego w murach budowlanych. Przegląd Budowlany. 2010;9:46-8.

16. Hoła J., Matkowski Z. Wybrane problemy dotyczące zabezpieczeń przeciwwilgociowych ścian w istniejących obiektach murowanych. In: Awarie budowlane, XXIV Konferencja NaukowoTechniczna. Szczecin-Międzyzdroje; 2009;73-92.

17. Wyrwał J, Świrska J. Problems of moisture in building walls. Warszawa: Komitet Inżynierii Lądowej i Wodnej PAN; 1998 (in Polish).

18. Espinosa RM, Franke L, Deckelmann G. Phase changes of salts in porous materials. Crystallization, hydration and deliquescence. Constr Build Mater. 2008;22:1758-73.

19. Gentillini C, Franzoni E, Brandini S, Nobile L. Effect of salt crystallization on the shear behavior of masonry walls. An experimental study. Constr Build Mater. 2012;37:181-9.

20. Wołoch F, Gaczek M, Fiszer S. Oddziaływanie soli na elementy budynku. Builder. 2017;12:70-4. 
21. Kosiński P, Wójcik R. Thermal and mycological nondestructive active protection of baroque buildings. Sci Technol Built Environ. 2019;25(9):1244-52.

22. Płoński W. Problemy wilgoci w przegrodach budowlanych. Warszawa: Wydawnictwo Arkady; 1968.

23. Ważny J, Karyś J. Ochrona budynków przed korozją biologiczną. Warszawa: Wydawnictwo Arkady; 2001.

24. Klosowski G, Kozlowski E, Niderla K, Rymarczyk P, Rymarczyk T. Process analysis with electrical impedance and capacitance tomography data. In: 2019 Applications of Electromagnetics in Modern Engineering and Medicine, PTZE 2019;8781714:161-65

25. Adamkiewicz P, Niderla K, Rymarczyk T, Sikora J, Tchorzewski P. Examination of moisture condition of buildings using electrical tomography. In: 2019 applications of electromagnetics in modern engineering and medicine, PTZE 2019;8781689:193-97.

26. Bednarczuk P, Klosowski G, Kozlowski E, Rymarczyk T, Sikora J. Application of multi-source data for proces analysis in electrical tomography. Przegląd Elektrotechniczny. 2019;95(12):192-05.

27. Hoła A. Non-destructive testing of the damp walls of the basements in a gothic monastery. In: W: 12th European Conference on Non-destructive Testing [electronic document]: Gothenburg, Sweden, 2018 : proceedings/[European Federation of Non-Destructive Testing, Nordic NDT Societies. B.m.: b.w., 2018]. art. ECNDT0291-2018; p. 1-8.

28. Hoła A. The moisture condition of the brick walls in the basements of a medieval monastery. In: 3rd Scientific Conference environmental challenges in civil engineering (ECCE 2018). MATEC Web of Conferences 2018;174:01012.

29. Hoła A, Hoła J, Matkowski Z. Analysis of the moisture content of masonry walls in historical buildings using the basement of a medieval town hall as an example. Proc Eng. 2017;172:363-8.

30. Hoła A., Matkowski Z. Nondestructive testing of damp vault brickwork in a gothic-renaissance city hall. In: XIth European Conference on NDT: October 6-10, 2014, Prague, Czech Republic. Conference proceedings. Brno: Brno University of Technology, 2014;1-7.

31. Goetzke-Pala A. Identyfikacja wilgotności murów ceglanych na podstawie badań nieniszczących z wykorzystaniem sztucznych sieci neuronowych. In: Raporty Wydziału Budownictwa Lądowego i Wodnego Politechniki Wrocławskiej. 2016, Ser. PRE; no $1 .$, p. 377

32. Pala A, Hoła J. Influence of burnt clay brick salinity on moisture content evaluated by non-destructive electric methods. Arch Civ Mech Eng. 2016;16:101-11.

Publisher's Note Springer Nature remains neutral with regard to jurisdictional claims in published maps and institutional affiliations. 